\section{Water Relations of Container-grown Woody and Herbaceous Plants Following Antitranspirant Sprays}

\author{
Rita L. Hummel \\ Department of Horticulture and Landscape Architecture, Washington \\ State University Puyallup Research and Extension Center, Puyallup, \\ WA 98371
}

\begin{abstract}
Additional index words. Impatiens wallerana, impatiens, Lycopersicon esculentum, tomato, Malus sarentii, Sargent's crabapple, Petunia $\times$ hybrida, petunia, Ulmus parvifolia, Chinese elm, Viburnum plicatum tomentosum, doublefile viburnum, transpiration, xylem pressure potential, water stress, Vapor Gard, Envy, Wilt-Pruf, Folicote, UC86177
\end{abstract}

Abstract. Four film-forming antitranspirants, Vapor Gard, Envy, Wilt-Pruf, and Folicote, and a new metabolic antitranspirant UC86177 were applied to container-grown Ulmus parvifolia Jacq. (Chinese elm), Malus sargentii Rehd. (Sargent's crabapple), Viburnum plicatum tomentosum Thunb. (doubleflle viburnum), Lycopersicon esculentum Mill. 'Early Giant' (tomato), Petunia $\times$ hybrids Hort. Vilm-Andr. 'Royal Pearls' (petunia), and Impatiens wallerana Hook. f. 'Blitz Orange' (impatiens) plants. Water status was assessed by the following methods: transpiration as water loss per unit leaf area, wilt by visual evaluation, and xylem pressure potential (XPP) determined with a pressure chamber. Antitranspirant treatment had no beneficial effect on water status of doublefile viburnum. In comparison to control plants, results of wilt ratings, XPP, and transpiration measurements for the elm, crabapple, tomato, petunia, and impatiens plants can be summarized as follows: UC86177-treated plants showed significantly less stress in 11 measures and were not different once; Wilt-Pruf was beneficial 10 times and not different twice; Folicote was beneficial nine times and not different three times; Vapor Gard produced eight beneficial results and four similar results; and Envy was beneficial three times and no different nine times. Species differences in response to antitranspirants as well as differences in product efficacy were demonstrated. UC86177 antitranspirant was shown to be as or more effective in controlling water status than the film-forming antitranspirants and may have potential for protecting various plant species against water stress.

Soil water available to container-grown plants is limited by the container size. As container-grown crops reach the point of sale, the plants generally have a large top in relation to their soil volume and dry out very quickly if the soil water supply is not constantly monitored and replaced. During shipping and display at retail outlets, after purchase by the homeowner, and at transplanting, water stress can rapidly develop in container-grown plants. Antitranspirants may offer some protection against water stress by slowing moisture loss from plants. Although application of a film-forming antitranspirant to plants just before shipment or sale is an accepted practice by some nurseries, results of film-forming antitranspirant research have been inconsistent.

Film type antitranspirants extended the irrigation interval for up to 2 weeks in highway plantings of oleander (Davenport et al.,

Received for publication 3 July 1989. H/LA paper no. 89-19. Trade names are mentioned with the understanding that no discrimination is intended nor endorsement implied by the author or the university. The cost of publishing this paper was defrayed in part by the payment of page charges. Under postal regulations, this paper therefore must be hereby marked advertisement solely to indicate this fact.
1973), limited water use by onion plants (Lipe et al., 1982), increased summer transplanting success for photinia (Ponder et al., 1983), and, in conjunction with a growth retardant, aided in the production of hydrangea (McDaniel, 1985). In chrysanthemum (Martin and Link, 1978), apple (Weller and Ferree, 1978), and blueberry (Andersen et al., 1979) film-forming antitranspirants produced a short-term benefit, such as reduced transpiration, but, in the long term, caused deleterious effects such as phytotoxicity, leaf drop, and reduced flower and fruit size. Water loss from antitranspirant-treated cineraria was reduced when plants were grown in a shaded but not in an unshaded greenhouse (Tu et al., 1985). Film-forming antitranspirants were not effective in reducing moisture stress of flowering dogwood (Williams et al., 1987) and had no short- or long-term benefit when used at transplanting on 8-year-old citrus trees (Castle, 1983).

Many of the antitranspirant studies have examined the effect of one or two compounds on one plant species. In studies where more than one film-forming antitranspirant of the various products have been found (Davies and Kozlowski, 1974; Albrigo, 1977; Martin and Link, 1978; McDaniel, 1985; Inhas been examined, differences in efficacy gram and Burbage, 1986). While most re- searchers have used only one plant species, Davies and Kozlowski (1974) treated two and found species differences in response to filmforming antitranspirants.

The present study attempted to find an effective rate of a new metabolic antitranspirant and to test the effect of time of sale applications of the metabolic antitranspirant and four commercially available film-forming antitranspirants on the water status of container-grown woody and herbaceous plants of six species. Experiments were conducted in 1986 and again in 1988. Two methods of measuring water status were used in 1986 and three in 1988.

1986 experiments. Rooted cuttings of two woody plant species, doublefile viburnum and Chinese elm, were planted in 3.8-liter containers in Spring 1986. The growing medium consisted of 7 fir bark : 1.5 sphagnum peat : 1.5. pumice (by volume) amended with $\left(\mathrm{kg} \cdot \mathrm{m}^{-3}\right) 4.1$ limestone flour, 3.5 dolomite, 0.38 treble superphosphate, 0.14 ferric sulfate, 0.6 Micromax (Sierra Chemical, Milpitas, Calif.), 0.6 gypsum, and Osmocote 18-6-12 (18N-2.6P-1OK, Sierra) at a rate of $1.5 \mathrm{~kg} \mathrm{~N} / \mathrm{m}^{3}$. Containers were placed on a gravel nursery bed and kept well-watered with overhead sprinkler irrigation. Osmocote 18-6-12 was applied at $36 \mathrm{~g}$ as a topdressing to each container in mid-July.

Seeds of tomato 'Early Giant' were germinated in peatlite medium (W.R. Grace, Cambridge, Mass.) in flats and transplanted, 1 Aug. 1986, into $10-\mathrm{cm}(700 \mathrm{ml})$ pots containing peatlite medium. Plants were grown in the greenhouse, watered as needed, and fertilized weekly with Peter's 20-20-20 (20N8.8 P-16.6K, W.R. Grace) at a rate of 200 ppm N.

In Aug. 1986, plants were moved to a shadehouse (75\% light exclusion) before antitranspirant application. Antitranspirants were applied during the morning and early afternoon by spraying upper and lower leaf surfaces to run-off with a pressurized hand sprayer. In late afternoon, several hours after the antitranspirants had dried, plants were

Table 1. Influence of antitranspirant treatments applied in 1986 on xylem pressure potential (XPP) and wilting of tomato 'Early Giant' and Chinese elm.

\begin{tabular}{|c|c|c|c|c|}
\hline \multirow[b]{2}{*}{ Antitranspirant } & \multicolumn{2}{|c|}{ Chinese elm } & \multicolumn{2}{|c|}{$\begin{array}{c}\text { Tomato } \\
\text { 'Early Giant' }\end{array}$} \\
\hline & $\begin{array}{l}\text { Wilt } \\
\text { rating }\end{array}$ & $\begin{array}{c}\text { XPP } \\
(\mathrm{MPa})\end{array}$ & $\begin{array}{c}\text { Wilt } \\
\text { rating }\end{array}$ & $\begin{array}{c}\mathrm{XPP} \\
(\mathrm{MPa})\end{array}$ \\
\hline $\begin{array}{l}\text { Control } \\
\text { (deionized water) }\end{array}$ & & & & \\
\hline UC86177 & 1.0 & & $\begin{array}{l}2.1 \\
1.0\end{array}$ & $\begin{array}{l}-1.02 \\
-0.42\end{array}$ \\
\hline Vapor Gard & 2.3 & -1.77 & 2.0 & -0.86 \\
\hline Envy & 2. & & 2.8 & -1.06 \\
\hline Wilt-Pruf & 1 & -1 & 1.3 & -0.71 \\
\hline Folico & 2. & -1 & 1.5 & -0.63 \\
\hline $\mathrm{LSD}_{0.05}$ & 0.8 & 0.64 & 1.0 & 0.29 \\
\hline
\end{tabular}

${ }^{2}$ Wilting of plants was visually rated according to: $1=$ no wilting, $3=$ severely wilted. Wilt and XPP of Chinese elm were measured 7 days after the last watering (14 days after treatment application). Wilt and XPP of tomato were measured 4 days after the last watering ( 11 days after treatment application). 


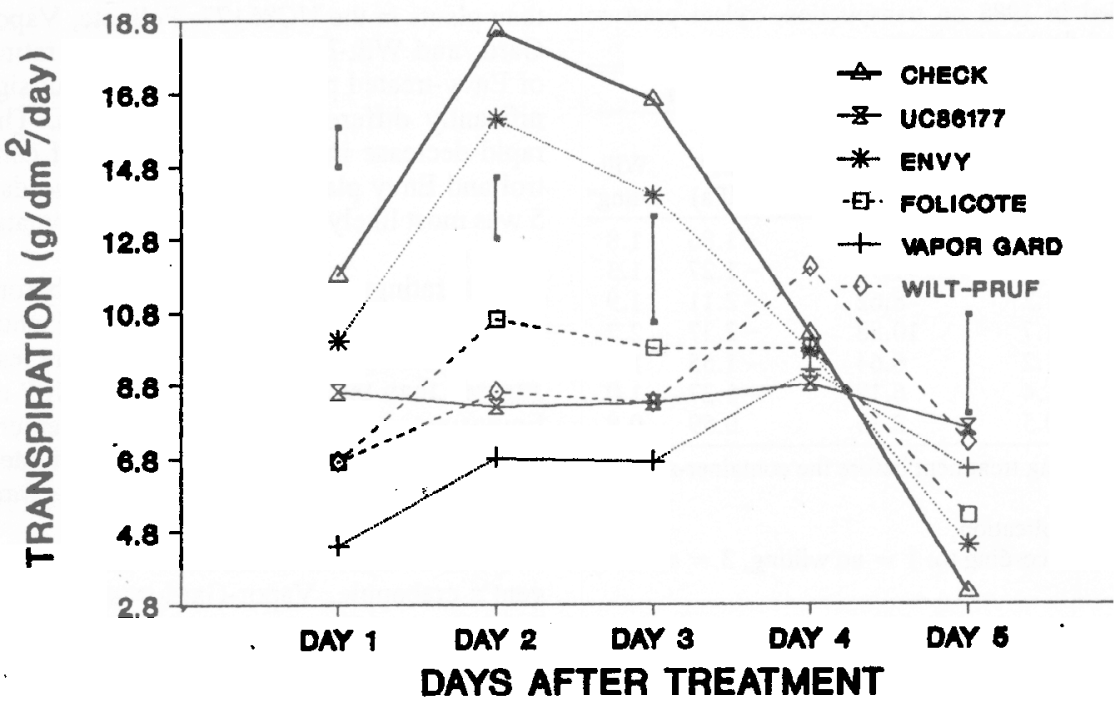

Fig. 1. Effect of antitranspirant treatment on daily transpiration of container-grown Sargent's crabapple. Bars on each day represent the LSD at 0.05 for that day, treatment differences were not significant on day 4.

moved into full sun in a greenhouse.

Two rates of the metabolic antitranspirant, UC86177, 1198 and $2396 \mathrm{mg}$ a.i./liter, were compared with the film-forming antitranspirants. UC86177 is a plant growth regulator with antitranspirant activity (Rhone-Poulenc Ag Co.; formerly Union Carbide Agricultural Products, Research Triangle Park, N.C.). UC86177 acts to reduce transpiration by a physiological-effect on the guard cell that persists for 10 to 21 days, depending upon the plant species (Rhone-Poulenc Ag Co. Information Sheet. Feb. 1988). UC86177 was formulated as an $80 \%$ a.i. solution in 1986 and as an $80 \%$ a.i. wettable powder in 1988 . In both years, instructions required that the active ingredient must be tank-mixed only with the antitranspirant adjuvant supplied by the company just before application.

The following film-forming antitranspirants were tested at the manufacturer's recommended rates: $2.5 \%$ Vapor Gard (di-1-pmenthene, Miller Chemical Corp., Hanover, Pa.); 10\% Envy (a hydrophyllic polymer, Safer, Inc., Wellesley, Mass.); 10\% WiltPruf (a water-based pine oil emulsion, Nursery Specialty Products, Greenwich, Corm.); 5.3\% Folicote (a hydrocarbon wax emulsion, Crystal Soap and Chemical, Lansdale, $\mathrm{Pa}$ ). Label directions do not call for the addition of surfactant and none was added to the film-forming antitranspirants. Control plants were treated with deionized water. Plants were kept well-watered and observed for signs of phytotoxicity following antitranspirant treatment.

One week following antitranspirant treatment, plants were given a final watering to container capacity. No more water was applied to. these plants. When water stress symptoms began to develop, plants were visually rated for wilting: 1 = no wilting, $2=$ slight wilting, $3=$ severely wilted, Wilt of elm and tomato plants was monitored daily until the mean wilt rating of at least one treatment exceeded 2.5. At that point, xylem pressure potential of all plants was measured with a Scholander pressure chamber (Scholander et al., 1965). When pressure chamber measurements are used to estimate the water potential $(\Psi)$ existing in the xylem, they can be referred to as xylem pressure potential (XPP), as recommended by Ritchie and Hinckley (1975). Viburnum XPP was measured when plants were only slightly wilted. XPP was determined during midday on samples wrapped in moist toweling, inserted in a plastic bag, then severed from the plant and immediately measured in the pressure chamber. For tomato, XPP of the second fully expanded leaf from the apex was measured. For elm, XPP was determined on stems severed below the third fully expanded leaf, and for viburnum, on stems severed below the second fully expanded leaf pair from the apex.

1988 experiments. Seedlings of Sargent's crabapple and rooted cuttings of doublefile viburnum were potted into 3.8-liter containers in Summer 1987. The growing medium and cultural practices were the same as those used in 1986. Plants were overwintered in a fiberglass house, moved back to the gravel nursery bed, and topdressed with $36 \mathrm{~g}$ of Osmocote 18-6-12 in Spring 1988.

Seeds of two popular bedding plant species, petunia 'Royal Pearls' and impatiens 'Blitz Orange', were germinated and the seedlings transplanted on 8 Aug. 1988. Growing media and cultural practices were as described for the 1986 herbaceous plants.

Woody plants were treated with antitranspirants in mid-August, and the herbaceous plants in Sept. 1988. Antitranspirant application methods and treatments were the same as in 1986. Treatments were applied in the shadehouse and plants were moved to the greenhouse in late afternoon, several hours after the antitranspirants dried on the foliage. Plants were observed for signs of phytotoxicity following treatment.

Transpiration was determined gravimetrically (Kramer, 1969) on all plants by sealing the container (medium at container capacity) in a polyethylene bag and determining weight loss at successive 24-hr intervals immediately following antitranspirant application. Wilt was monitored daily until the mean wilt rating of at least one treatment per species exceeded 2.5. The final wilt rating and weight measurement were then taken and stem XPP of each plant was determined as described for the 1986 experiments. Stems were severed under the second (viburnum) or third (crabapple, impatiens, and petunia) fully expanded leaf. Finally, leaf areas of all plants were determined with aLI-CORModelLI3000 (LI-COR, Lincoln, Neb.) leaf area meter. Transpiration was calculated as $\mathrm{g} \cdot \mathrm{d} \mathrm{m}^{-2} \cdot \mathrm{day}^{-1}$.

The experiments were designed as randomized complete blocks with six replications. The more desirable concentration of UC86177 to be used for testing against the film-forming antitranspirants was determined by analysis of variance (ANOVA) and Student's $t$ test. ANOVA was used to determine significance of antitranspirant treatments and a protected Fisher's least significant difference-test was used to make the following comparisons: antitranspirant treatments with the control and UC86177 antitranspirant with the film-forming antitranspirants. Wilt rating analysis produced the same results whether the actual values or arcsin square root-transformed values were used. Wilt ratings are presented as actual values for ease of comparison.

Results for 1986. No phytotoxicity was observed on the Chinese elm or doublefile viburnum plants. Avery slight stippling and slight curling was noticed on some of the tomato leaves treated with UC86177. In comparison to the controls, both rates of UC86177 significantly improved the water status of elm and tomato plants as measured by XPP and visual wilt symptoms. While the response to 1198 and $2396 \mathrm{mg}$ a.i./liter was similar, plants treated with the higher rate showed a slight improvement in water status (data not shown). UC86177 had no effect on water stress of doublefile viburnum. UC86177 at $2396 \mathrm{mg}$ a.i. was chosen for testing with the film-forming antitranspirants.

Wilt ratings of elms in containers made just before the XPP measurements indicated the UC86177- and Wilt-Pruf-treated plants were less water stressed than the controls, while plants treated with Vapor Gard, Envy, and Folicote were not significantly different from controls (Table 1). Elms treated with UC86177 showed no visible symptoms of wilt. Xylem pressure potentials of elms treated with antitranspirants, regardless of type, were higher than for control plants (Table 1). The highest XPP of the antitranspirant-treated elms were for the UC86177-treated plants; however, the XPP values of the UC86177 plants were not significantly higher than plants in the Vapor Gard and Wilt-Pruf treatments.

UC86177-, Wilt-Pruf-, and Folicote-treated tomato plants were not as wilted as and had higher XPP measurements than the controls (Table 1). Treatment. with Vapor Gard and Envy produced no improvement over the controls, according to both methods of measuring water status. Wilt and XPP results for 
Table 2. Influence of antitranspirant treatments applied in 1988 on transpiration, xylem pressure potential (XPP), and wilting of Sargent's crabapple and doublefile viburnum.

\begin{tabular}{|c|c|c|c|c|c|c|}
\hline \multirow[b]{2}{*}{ Antitranspirant } & \multicolumn{3}{|c|}{ Sargent's crabapple } & \multicolumn{3}{|c|}{ Doublefile viburnum } \\
\hline & $\begin{array}{c}\text { Mean rate of } \\
\text { transpiration } \\
\left(\mathrm{g} \cdot \mathrm{dm}^{-2} \cdot \text { day }^{-1}\right)\end{array}$ & $\begin{array}{l}\text { XPPy } \\
(\mathrm{MPa})\end{array}$ & $\begin{array}{c}\text { Wilt } \\
\text { rating }^{\mathbf{x}}\end{array}$ & $\begin{array}{c}\text { Mean rate of } \\
\text { transpiration } \\
\left(\mathrm{g} \cdot \mathrm{dm}^{-2} \cdot \mathrm{day}^{-1}\right)\end{array}$ & $\begin{array}{l}\text { XPPy } \\
(\mathrm{MPa})\end{array}$ & $\begin{array}{l}\text { Wilt } \\
\text { rating }\end{array}$ \\
\hline Control (deionized water) & 15.13 & -3.32 & 2.6 & 8.06 & -1.86 & 1.8 \\
\hline UC86177 & 8.41 & -2.15 & 1.4 & .7 .96 & -1.27 & 1.3 \\
\hline Vapor Gard & 5.60 & -1.69 & 1.2 & 8.62 & -2.11 & 1.9 \\
\hline Envy & 13.04 & -2.85 & 1.7 & 10.88 & -2.37 & 2.7 \\
\hline Wilt-Pruf & 7.66 & -2.31 & 1.2 & 6.64 & -1.55 & 1.7 \\
\hline Folicote & 8.67 & -2.18 & 1.4 & 6.19 & -1.27 & 1.0 \\
\hline $\mathrm{LSD}_{0.05}$ & 1.39 & 0.96 & 0.5 & 2.35 & 0.59 & 0.8 \\
\hline
\end{tabular}

${ }^{z}$ Transpiration values are the average of the first 2 days following treatment before the container-medium water supply became limiting.

${ }^{\mathrm{X}} \mathrm{XP}$ was measured during midday 5 days after treatment application.

xWilting of plants was visually rated, 5 days after treatment, according to: $1=$ no wilting, $3=$ severely wilted.

Table 3. Influence of antitranspirant treatments applied in 1988 on transpiration, xylem pressure potential (XPP), and wilting of petunia 'Royal Pearls' and impatiens 'Blitz Orange'.

\begin{tabular}{|c|c|c|c|c|c|}
\hline \multirow[b]{2}{*}{ Antitranspirant } & \multicolumn{3}{|c|}{ Petunia 'Royal Pearls' } & \multicolumn{2}{|c|}{ Impatiens 'Blitz Orange' } \\
\hline & $\begin{array}{l}\text { Mean rate of } \\
\text { transpiration } \\
\left(\mathrm{g} \cdot \mathrm{dm}^{-2} \cdot \mathrm{day}^{-1}\right)\end{array}$ & $\begin{array}{l}\text { XPPy } \\
(\mathrm{MPa})\end{array}$ & $\begin{array}{l}\text { Wilt } \\
\text { rating }\end{array}$ & $\begin{array}{l}\text { Mean rate of } \\
\text { transpiration } \\
\left(\mathrm{g} \cdot \mathrm{dm}^{-2} \cdot \text { day }^{-1}\right)\end{array}$ & $\begin{array}{l}\text { Wilt } \\
\text { rating }\end{array}$ \\
\hline Control (deionized water) & 11.46 & -1.22 & 2.6 & 13.11 & 2.8 \\
\hline UC86177 & 6.59 & -0.49 & 1.6 & 9.78 & 2.7 \\
\hline Vapor Gard & 8.12 & -0.80 & 2.4 & 9.30 & 2.2 \\
\hline Envy & 12.30 & -0.95 & 2.7 & 11.65 & 2.8 \\
\hline Wilt-Pruf & 10.05 & -0.64 & 2.3 & 9.52 & 2.3 \\
\hline Folicote & 9.34 & -0.81 & 2.0 & 10.27 & 2.7 \\
\hline $\mathrm{LSD}_{0.05}$ & 1.84 & $\cdot 0.36$ & 0.6 & 1.63 & 0.4 \\
\hline
\end{tabular}

${ }^{z}$ Transpiration values are the average of the first 2 days following treatment before the container-medium water supply became limiting.

YXPP was measured during midday 4 days after treatment application.

WWilting of plants was visually rated, 4 days after treatment, according to: $1=$ no wilting, $3=$ severely wilted.

UC86177, Wilt-Pruf, and Folicote were similar. In comparison to UC86177, Envy-treated tomato plants were more wilted and had lower XPP. Wilting in response to Vapor Gard and UC86177 was similar, but XPP of the Vapor Gard plants was lower.

Antitranspirant treatments had no significant effect on XPP measurements and wilt ratings of doublefile viburnum plants (data not shown). Davies and Kozlowski (1974) have also reported species differences in response to antitranspirants. Because of its lack of response, doublefile viburnum was retested in the 1988 experiments.

Results of the 1986 experiments showed UC86177 and Wilt-Pruf consistently improved the water status as measured by visual wilt symptoms and XPP of elm and tomato plants. Results with the other film-forming antitranspirants were more variable. When considering results of wilt rating and XPP for both elm and tomato, Folicote produced a significant improvement over the controls in three of the -four measures, while Envy and Vapor Gard improved only the XPP of elms. The differences in visual wilt ratings for elm and tomato, in general, paralleled the differences in XPP, the objective measure of water stress. Results for doublefile viburnum were more variable and did not demonstrate a consistent benefit from any of the antitranspirant treatments.

Results for 1988. The day following ap- than plants in the UC86177, Folicote, Vapor Gard, and Wilt-Pruf treatments. Wilt rating of Envy-treated plants on day 4 was not significantly different from the controls. The rapid decrease in transpiration rates of control and Envy plants between day 3 and day 5 was most likely due to wilting and stomatal closure

Wilt ratings made on day 5 , just before the XPP measurements, indicated all antitranspirant-treated crabapple plants were less stressed than the controls (Table 2). XPP of Envy-treated plants showed no improvement over the controls, but the XPP of plants treated with the other antitranspirants was improved.

When compared to UC86177-treated Sargent's crabapple, Vapor-Gard-treated plants had lower and Envy-treated plants had higher transpiration rates. There were no other significant differences between UC86177- and film-forming antitranspirant-treated crabapples (Table 2).

All three measures of water status indicated antitranspirant treatments did not reduce water stress in doublefile viburnum (Table 2). Transpiration and wilt rating results indicated Envy-treated viburnums were more stressed than the controls. Envy-treated plants were more stressed than UC86177 plants by all water status measures, while only XPP indicated Vapor Gard plants were more stressed than the UC86177 plants (Table 2). Other differences between UC86177 and film-forming antitranspirant-treated viburnums were not significant. Daily transpiration patterns also showed that the antitranspirant treatments had no positive impact on doublefile viburnum water status (data not shown). These results are in agreement with those for 1986, which showed that antitranspirant treatments had no effect on doublefile viburnum.

In petunia, the average transpiration rate for the first 2 days following treatment was lower than for the controls for UC86177, Vapor Gard, and Folicote treatments, while Envy- and Wilt-Pruf-treated plants had transpiration rates similar to the control plants (Table 3). Only UC86177-treated petunias were less wilted than the controls. XPP measurements indicated petunia plants in all antitranspirant treatments except Envy were less stressed than the control plants. Transpiration rate in the Envy, Wilt-Pruf, and Folicote treatments was greater than in the UC86177 treatment, while Vapor Gard, Envy, and WiltPruf plants were more wilted than the UC86177 plants. Based on XPP, only Envytreated plants were more stressed than the UC86177-treated plants. In general, petunias treated with UC86177 transpired the least amount of water, had the highest XPP, and were the least wilted; however, these differences were not significant from some of the other antitranspirant treatments (Table 3).

Transpiration rates of impatiens were lowered by treatment with UC86177, Vapor Gard, Wilt-Pruf, and Folicote. Envy-treated plants had transpiration rates similar to the controls. Vapor Gard- and. Wilt-Pruf-treated impatiens were less wilted than control plants. 
In comparison to UC86177-treated plants, those in the Envy treatment had higher transpiration rates, while plants in the Vapor Gard treatment were less wilted: other differences were not significant. XPP of impatiens is not reported because of difficulties encountered in measuring XPP of the stems. Impatiens stems are succulent and when pressure was applied, a clear sap oozed from the cut surface of the stem, covered the xylem, and made it impossible to detect water coming from the xylem vessels.

In summary, of the 15 possible outcomes for each antitranspirant compound the results were: UC86177-treated plants were significantly less stressed than the controls 11 times and not significantly different from controls four times; Wilt-Pruf lowered stress levels 10 times and was not different five times; Folicote was beneficial nine times, no different six times; Vapor Gard produced eight beneficial and seven similar results; and Envytreated plants were less stressed than the controls three times, no different 10 times, and more stressed twice.

Treatment with UC86177, the metabolic antitranspirant, or the four film-forming antitranspirants produced no significant beneficial effect on the water status of doublefile viburnum in either the 1986 or 1988 experiments. Species differences in response to film-forming antitranspirants have been reported by Davies and Kozlowski (1974) and attributed to differences in stomatal anatomy (Andersen et al., 1979). Results with doublefile viburnum seem to indicate that there may be species differences in the efficacy of UC86177.

In these experiments, UC86177 antitranspirant was shown to be as effective or more so than the film-forming products tested for short-term amelioration of water stress in container-grown plants. As a metabolic antitranspirant with a 10- to 21-day efficacy period (Rhone-Poulenc Information Sheet, Feb. 1988), UC86177 may have potential for producing the short-term benefit of protection against- water stress without the longterm deleterious effects associated with the film-forming antitranspirants (Davies and Kozlowski, 1974; Martin and Link, 1978; Andersen et al., 1979). Additional studies with UC86177 are needed to determine activity, optimal rate of application, efficacy period, and potential for reapplication on various plant species.

\section{Literature Cited}

Albrigo, L.G. 1977. Comparison of some antitranspirants on orange trees and fruit. J. Amer. Soc. Hort. Sci. 102(3):270-273.

Andersen, P. C., D.W. Buchanan, and L.G. Albrigo. 1979. Antitranspirant effects on water relations and fruit growth of rabbiteye blueberry. J. Amer. Soc. Hort. Sci. 104(3):378-383.

Castle, W.S. 1983. Antitranspirant and root and canopy pruning effects on mechanically transplanted eight-year-old 'Murcott' citrus trees. J. Amer. Soc. Hort. Sci. 108(6):981-985.

Davenport, D. C., P.E. Martin, and R.M. Hagen. 1973. Effects of an antitranspirant on water use by highway oleander (Nerium oleander L.) plantings. J. Amer. Soc. Hort. Sci. 98(5):421425.

Davies, W.J. and T.T. Kozlowski. 1974. Shortand long-term effects of antitranspirants on water relations and photosythesis of woody plants. J. Amer. Soc. Hort. Sci. 99(4):297-304.

Ingram, D.I. and W. Burbage. 1986. Transplanting trees in risky situations-do anti-transpirants and additives help? Amer. Nurseryman 164(3):81-82, 84-85.

Kramer, P.J. 1969. Plant and soil water relationships: A modern svnthesis. McGraw-Hill, New York.

Lipe, W. N., K. Hodnett, M. Gerst, and C.W. Wendt. 1982. Effects of antitransuirants on water use and yield of greenhouse and field-grown onions. HortScience 17(2):242-244.

Martin, J.D. and C.B. Link. 1978. The potential use of antitranspirants in the greenhouse production of chrysanthemum. J. Amer. Soc. Hort. Sci. 103(3):327-331.

McDaniel, G.L. 1985. Transpiration of hydrangea as affected by antitranspirants and chlormequat.
HortScience 20(2):293-296.

Ponder, H. G., C.H. Gilliam, and H.J. Dawes. 1983. Factors affecting postharvest stress of summer-dug photinia. HortScience 18(1):83-85.

Ritchie, G.A. and T.M. Hinckley. 1975. The pressure chamber as an instrument for ecological research. Adv. Ecol. Res. 9:165-264.

Scholander, P. F., H.T. Hammel, E.D. Bradstreet, and E.A. Hemmingsen. 1965. Sap pressure in vascular plants. Science 148:339-345.

Tu, Z. P., A.M. Armitage, and H.M. Vines. 1985. Influence of an antitranspirant and a hydrogel on net photosynthesis and water loss of cineraria during water stress. HortSciencc 20(3):386 388.

Weller, S.C. and D.C. Ferree. 1978. Effect of a pinolene-base antitranspirant on fruit growth, net photosynthesis, transpiration, and shoot growth of 'Golden Delicious' apple trees. J. Amer. Soc. Hort. Sci. 103(1):17-19.

Williams, J. D., H.G. Ponder, and C.H. Gilliam. 1987. Reducing moisture stress in Comus florida. J. Environ. Hort. 5(3):131-133.

\title{
Skin Color in 'Newtown' Apples Treated with Calcium Nitrate, Urea, 'Diphenylamine, and a Film Coating
}

\author{
M. Meheriuk \\ Agriculture Canada Research Station, Summerland, British Columbia \\ VOH 1ZO, Canada
}

Additional index words. skin injury, Malus domestics

Abstract. 'Newtown' apples (Malus domestics Borkh.) treated weekly with urea at 10 $\mathrm{g} \cdot \operatorname{liter}^{-1}$ or $\mathrm{Ca}\left(\mathrm{NO}_{3}\right)_{2}$ at $7.5 \mathrm{~g} \cdot$ liter-1 for 5 consecutive weeks from late August were greener at harvest and during storage than comparable control fruit. A postharvest dip in Nutri-Save, a polymeric coating, was better for retention of skin greenness than a dip in diphenylamine and both gave greener apples than control (nondipped) fruit. Fruit treated with $\mathrm{Ca}\left(\mathrm{NO}_{3}\right)_{2}$ displayed lesions that were larger and more numerous than typical bitter pit in the control fruit.

Although 'Newtown' apples are green during growth, they have a tendency to turn yellow late in the growing season. Yellow skin renders them less attractive to consumers accustomed to 'Granny Smith', the competing cultivar that cannot be grown in British Columbia because the growing season is too short. Treatments that influence skin greenness are high $\mathrm{N}$ levels (Williams and Billingsley, 1974; Vang-Peterson et al., 1977; Saitoh et al., 1983), $\mathrm{Ca}\left(\mathrm{NO}_{3}\right)_{2}$ sprays (Jones, 1980), and dips in diphenylamine solutions (Little and Taylor, 1981). A 2-year study was conducted at the Summerland Research Station to assess the influence of preharvest sprays of urea and $\mathrm{Ca}\left(\mathrm{NO}_{3}\right)_{2}$ and

Received for publication 17 Apr. 1989. Agriculture Canada Research Station, Summerland, B.C. Contribution no. 733. The cost of publishing this paper was defrayed in part by the payment of page charges. Under postal regulations, this paper therefore must be hereby marked advertisement solely to indicate this fact. postharvest dips in diphenylamine (DPA) and Nutri-Save (a proprietary fruit coating; Nova Chem, Halifax, N. S., Canada) on retention of skin greenness in 'Newtown' apples. Results on skin color, firmness, acidity, soluble solids concentration, and ripening are reported in this paper.

A block of 'Newtown' apples planted in 1981 at the station was used in this study and trees received the same treatment in both years. Three rootstock and three training systems were present in the 'Newtown' block. However, only two of the training systems were used in the study and treatments were applied to the same plots within the six completely randomized blocks. Plots consisted of two or three trees, depending on the rootstock $\mathbf{x}$ tree training combination. Urea at $10 \mathrm{~g} \cdot$ liter $^{-1}$ and $\mathrm{Ca}\left(\mathrm{NO}_{3}\right)_{2}$ at $7.5 \mathrm{~g} \cdot$ liter $^{-1}$ $(\mathrm{w} / \mathrm{v})$ were applied at weekly intervals for 5 weeks, commencing at the end of Aug. 1986 and 1987. Control trees within each block were left unsprayed. A box of fruit $(\approx 80$ fruits) was harvested at commercial maturity 